\title{
cDNA Cloning and Characterization of Three Genes Uniquely Expressed in Cerebellum by Purkinje Neurons
}

\author{
Daniel T. Nordquist, ${ }^{1}$ Christine A. Kozak, ${ }^{2}$ and Harry T. Orr ${ }^{1}$ \\ 'Institute of Human Genetics, and Department of Laboratory Medicine and Pathology, University of Minnesota, \\ Minneapolis, Minnesota 55455, and 2Laboratory of Molecular Microbiology, National Institute of Allergy and Infectious \\ Diseases, National Institutes of Health, Bethesda, Maryland 20892
}

The characteristics that distinguish the different neuronal cell types of an organism are believed to be primarily determined by unique patterns of cellular gene expression. The identification of cell-type specific molecules should therefore provide a good basis for understanding the biology of specific neuron types. In this paper, we describe the isolation of cDNA clones corresponding to mRNA uniquely expressed by Purkinje cells in mature mouse cerebellum. Three cDNA clones were selected from a library of normal mouse cerebellar cDNA by virtue of their failure to hybridize to mRNA sequences from the cerebella of Purkinje cell degeneration (pcd) mice. The cDNA clones were shown by in situ and Northern hybridization to correspond with mRNA present in Purkinje cells but absent or at low levels in other cell types of the cerebellum. By sequence analysis, clone PCD29 was determined to encode the calcium-binding protein calbindin$D_{28 k}$. Clones PCD5 and PCD6 encode previously undescribed proteins of 99 and $>500$ amino acids, respectively. All 3 PCD clones hybridized to mouse mRNA from sources other than cerebelium; clone PCD5 was found to have the most restricted expression, as it hybridized only to mRNA from cerebellum and eye. To define potential correlations between the PCD clones and mutations in the mouse genome known to affect Purkinje cells, clones PCD5, PCD6, and PCD29 were localized to mouse chromosomes 8,6 , and 4 , respectively.

The application of monoclonal antibody and molecular cloning techniques to the study of the nervous system has demonstrated that neurons can be classified into related groups based on their molecular constituents. A given type of neuron can thus be assumed to differ from other neurons by virtue of a unique pattern of gene expression that determines its characteristic physiological and morphological features. One approach by which to correlate gene expression with the cellular phenotype of a neuron would be to identify and characterize a number of gene products that uniquely define a specific neuron type. In the mouse, several mutants exist that are specifically deficient in the Purkinje cells of cerebellum (Sidman, 1983) and could serve to define Purkinje cell molecules not expressed by other cerebellar cell types. The existence of thesc genctic mutants thus

\footnotetext{
Received Mar. 2, 1988; revised Apr. 19, 1988; accepted Apr. 20, 1988.

This work was supported by Grant NS 22920 from the NIH.

Correspondence should be addressed to Dr. Harry T. Orr, Department of Laboratory Medicine and Pathology, Box 198 UMHC, 420 Delaware Street, S.E., Minneapolis, MN 55455.

Copyright (C) 1988 Society for Neuroscience $0270-6474 / 88 / 124780-10 \$ 02.00 / 0$
}

provides a strong basis for a molecular analysis of Purkinje cell phenotype.

Since the cerebellum is amenable to a variety of analyses, there is a reasonable chance of correlating Purkinje cell molecules with cell structure or function. The cerebellum itself has been thoroughly examined at a physiological and structural level, resulting in a basic understanding of the neural circuitry of the cerebellar cortex and the role of the Purkinje cells (reviewed by Ito, 1984). In addition, the Purkinje cells have been studied in cerebellar explant cultures, which generate functioning networks resembling in vivo structure (Weber and Schachner, 1984; Gruol and Franklin, 1987). The identification of molecules unique to the Purkinje cells could allow experimental manipulation of this network in vitro. Correlation of Purkinje cell molecules with cellular phenotype might also be achieved through analysis of mouse mutants having defects in cerebellar structure or function. Over 20 such mutations have been described in the mouse (reviewed by Sidman, 1983). Some of these mutants, such as hyperspiny Purkinje cell $(h p c)$ and staggerer $(s g)$, suggest an arrest of the developmental program of gene expression in Purkinje cells and may be useful in assigning a gene to a particular aspect of development. Since many of the mutations have been mapped on the mouse chromosomes (Roderick and Davisson, 1984), it should also be possible to assess their relationship to any cloned Purkinje cell molecules by genetic linkage analysis.

A number of molecules have already been localized to the Purkinje cells. These include a cGMP-dependent protein kinase (Lohmann et al., 1981), the calcium binding protein calbindin$\mathrm{D}_{28 \mathrm{~K}}$ (Jande et al., 1981), and the peptides motilin (Nilaver et al., 1982) and cerebellin (Slemmon et al., 1985). In this paper, however, we describe a more systematic approach to the isolation of cDNA clones uniquely expressed in mature Purkinje cells. This involves a selective cloning procedure that compares cerebellar gene expression in normal mice and in mice affected by the Purkinje cell degeneration ( $p c d$ ) mutation (Mullen et al., 1976). In an initial experiment, we isolated $3 \mathrm{cDNA}$ clones from normal adult cerebellar mRNA that did not hybridize to 6 week $p c d$ cerebellar mRNA; their expression in Purkinje cells was confirmed by in situ hybridization. We present the initial characterization of these clones by DNA sequence analysis and by their pattern of mRNA expression. One of the clones, PCD29, encodes the protein calbindin- $D_{28 \mathrm{~K}}$ (Wasserman, 1985); the remaining clones, PCD5 and PCD6, represent previously undescribed gene products. None of the mRNA species corresponding to these cDNA clones is cerebellum specific, as they were found in other brain regions and in non-neural tissues. To define 
potentially equivalent genes among the known cerebellar mutants, genes corresponding to PCD5, PCD6, and PCD29 were mapped to mouse chromosomes.

\section{Materials and Methods}

Mice. C57BL/6J-pcd/pcd mice were supplied by the Jackson Laboratory. All other inbred strains of mice were bred and maintained at the breeding facilities of the University of Minnesota.

Enzymes and biochemicals. Enzymes and ribonuclease inhibitor were purchased from Bethesda Research Laboratories, New England Biolabs, and Pharmacia. Nick-translation kits were purchased from Amersham, and radioisotopes were from New England Nuclear. Deoxy- and dideoxynucleotides were purchased from Pharmacia. Oligo(dA)- and oligo(dT)-cellulose were purchased from Collaborative Research. Chemicals for RNA isolation were purchased from International Biotechnologies, Inc.

RNA isolation. Total cellular RNA was isolated from pulverized, frozen tissue by the guanidinium thiocyanate method, with purification through $2 \mathrm{CsCl}$ cushions (Chirgwin et al., 1979). Cytoplasmic RNA was isolated from fresh tissue, which was homogenized on ice as described (Hall and Lim, 1984) in the presence of 150 units/ml placental RNase inhibitor, lysed with $1 \%$ Triton X-100, and centrifuged at $1470 \times g$ to remove nuclei. The cytoplasmic supernatant was then added to 2 vol of a $1.5 \times$ guanidinium thiocyanate lysis solution, and RNA purified through a $\mathrm{CsCl}$ cushion as above. Poly(A)+ RNA was isolated by oligo(dT)-cellulose chromatography as described by Padgett et al. (1979).

Plasmid vectors. The single-strand DNA plasmids pUC118 and pUC1 19, and helper phage M13K07 have been described by Vieira and Messing (1987). Plasmid pCM4119 was derived from pUC119 by sequential treatment with Sca I endonuclease and $\mathrm{Ba} 131$ exonuclease to remove the $\beta$-lactamase gene, followed by ligation to the chloramphenicol acyltransferase gene from pACYC184.

cDNA libraries. Plasmid vectors pUC118 and pCM4119 were used for constructing cDNA libraries from 6 week normal and pcd total cellular poly(A)+ cerebellar RNA (libraries AW and SP, respectively) by a modified vector-primed procedure (Okayama and Berg, 1982). Poly(T) tails (average length $60 \mathrm{nt}$ ) were added with terminal transferase to Kpn I-digested vector, followed by $\mathrm{Xba}$ I digestion to remove one tail. The large fragment was purified by agarose gel electrophoresis and oligo(dA)-cellulose chromatography. First strand cDNA was synthesized with M-MLV reverse transcriptase (BRL) according to manufacturer recommendations, using $2 \mu \mathrm{g}$ poly(T)-tailed vector-primer and 4 $\mu \mathrm{g}$ poly(A)+ RNA (100 $\mu$ l reaction vol). First strand cDNA was extracted with phenol, chloroform, and ether, and microdialyzed (Marusyk and Sergeant, 1980) on a $0.05 \mu \mathrm{m}$ VM membrane (Millipore) against $10 \mathrm{~mm}$ Tris- $\mathrm{HCl}$ (pH 7.4), $1 \mathrm{~mm}$ EDTA for $2 \mathrm{hr}$ on ice. An RNaseHPol I reaction (Gubler and Hoffman, 1983) was then performed $(200 \mu \mathrm{l}$ reaction vol) to create blunt-ended, double-strand cDNA and to remove any unused poly(T) tails. The cDNA was extracted with phenol and chloroform, concentrated with butanol to $40 \mu \mathrm{l}$, and ethanol-precipitated. After resuspension, the blunt-ended cDNA was recircularized with T4 DNA ligase for $20 \mathrm{hr}$ at $15^{\circ} \mathrm{C}$ in a buffer containing $1 \mathrm{~mm}$ spermidine, $50 \mathrm{~mm}$ Tris- $\mathrm{HCl}$ (pH 7.4), $10 \mathrm{mM} \mathrm{MgCl}_{2}, 10 \mathrm{~mm}$ DTT, 1 $\mathrm{mM}$ ATP, and $10 \mu \mathrm{g} / \mathrm{ml}$ acetylated BSA. DNA was microdialyzed as before and diluted to $200 \mu \mathrm{l}$. Forty aliquots of $5 \mu \mathrm{l}$ were used to transform E. coli strain MV1190 (Vieira and Messing, 1987) by the method of Hanahan (1984). Clones were amplified on nitrocellulose filters and frozen in liquid aliquots as described (Hanahan, 1984). Libraries AW and SP each contained more than $40 \%$ nonrecombinants, with approximately 100,000 recombinant clones each. A library of normal cytoplasmic poly (A) + cerebellar RNA (library AC) was similarly prepared in pUC1 18. In this case, one poly(T) tail was removed with Pst I instead of Xba I, and 270 units $/ \mathrm{ml}$ placental RNase inhibitor was included in the reverse-transcriptase reaction. This library contained $20 \%$ nonrecombinants and yielded 400,000 recombinants.

Subtractive hybridization. Aliquots of the cDNA libraries AW and SP were thawed and diluted in LB medium to $10^{7}$ cells $/ \mathrm{ml}$, infected with M13K07 helper phage $\left(10^{8} / \mathrm{ml}\right)$, and grown overnight at $37^{\circ} \mathrm{C}$ with 25 $\mu \mathrm{g} / \mathrm{ml}$ kanamycin and either ampicillin or chloramphenicol. Packaged single-strand plasmid was precipitated from culture supernatant $15 \mathrm{~min}$ after addition of $0.15 \mathrm{vol}$ of $20 \%$ PEG $6000,2.5 \mathrm{M} \mathrm{NaCl}$; the precipitate was resuspended, extracted with phenol and chloroform, and ethanolprecipitated. Recombinant single-strand plasmid DNA was purified from contaminating nonrecombinants and M13K07 by oligo(dA)- or oli-
go(dT)-celluluse chromatography. Single-strand plasmid containing pcd cDNA was linearized by Eco RI digestion prior to subtraction, using an oligonucleotide to form the double-strand substrate (Dale et al., 1985). Maintaining the integrity of single-stranded plasmid during hybridization required using PERT conditions (Kohne et al., 1977): $1 \mu \mathrm{g}$ of normal cDNA plasmid, $16 \mu \mathrm{g} p c d$ cDNA plasmid, and $0.5 \mu \mathrm{g}$ oligo(dT) were shaken $5 \mathrm{~d}$ at $22^{\circ} \mathrm{C}$ in $0.48 \mathrm{~m}$ sodium phosphate ( $\left.\mathrm{pH} 7.4\right)$, in the presence of $10 \%$ phenol ( $200 \mu \mathrm{l}$ total vol). Following extraction with chloroform and ether, the reaction was diluted to $0.12 \mathrm{~m}$ phosphate and passed through hydroxylapatite at $60^{\circ} \mathrm{C}$. The unabsorbed, singlestrand DNA was butanol-concentrated, microdialyzed against $10 \mathrm{~mm}$ Tris $\mathrm{HCl}(\mathrm{pH} 7.4), 1 \mathrm{~mm}$ EDTA, and used to transform E. coli strain DH1 by the method of Hanahan (1984). Transformants were plated with ampicillin to select against remaining plasmid from the $p c d$ library. The enrichment of normal cDNA by this procedure was measured by determining the percentage of nonrecombinants in the single-strand DNA before and after subtraction.

Colony and plasmid screening. Colonies on nitrocellulose filters were replicated and prepared for hybridization as previously described (Hanahan and Meselson, 1983). Probe cDNA was prepared from $2 \mu \mathrm{g}$ total cellular poly(A) + RNA from normal cerebellum in a $1 \mathrm{hr}$ reaction at $37^{\circ} \mathrm{C}$ containing $10 \mu \mathrm{g} / \mathrm{ml}$ oligo $(\mathrm{dA}), 50 \mu \mathrm{g} / \mathrm{ml}$ actinomycin $\mathrm{D}, 1 \mathrm{~mm}$ dATP, $1 \mathrm{~mm}$ dGTP, $1 \mathrm{~mm}$ dTTP, $5 \mu \mathrm{M}$ dCTP, $500 \mu \mathrm{Ci}\left[\alpha^{32} \mathrm{P}\right]$-dCTP $(3000 \mathrm{Ci} / \mathrm{mmol}, 10 \mathrm{Ci} / \mathrm{ml})$ and 20 units $/ \mu 1 \mathrm{M}-\mathrm{MLV}$ reverse transcriptase (BRL) in the manufacturer-supplied buffer (150 $\mu$ l reaction vol). The yield was $0.12 \mu \mathrm{g}$ cDNA, with a specific activity of $8 \times 10^{8} \mathrm{cpm} /$ $\mu \mathrm{g}$. The probe was purified and precipitated as previously described (Davis et al., 1984) and allowed to decay $8 \mathrm{~d}$ at $-70^{\circ} \mathrm{C}$ to reach an average size of $300 \mathrm{nt}$. This was PERT-hybridized (Kohne et al., 1977) for $4 \mathrm{~d}$ to $20 \mu \mathrm{g} \mathrm{pcd}$ single-strand plasmid DNA in the presence of 0.48 M sodium phosphate ( $\mathrm{pH} 7.0)$ and $10 \%$ phenol (60 $\mu$ l volume). For the last $1 \mathrm{hr}$ of hybridization, $20 \mu \mathrm{g}$ denatured mouse genomic DNA was included in the hybridization. Duplex DNA was removed by hydroxylapatite chromatography as described above. The single-strand fraction was used to probe two $137 \mathrm{~mm}$ filters in a volume of $10 \mathrm{ml}$. Hybridization was at $42^{\circ} \mathrm{C}$ for $30 \mathrm{hr}$ using previously described conditions (Koller et al., 1985) except for the omission of dextran sulfate. Filters were washed at $68^{\circ} \mathrm{C}$ as described below for Northern blots and exposed to Kodak XAR 5 film for $5 \mathrm{~d}$ using intensifying screens.

Positive colonies and those surrounding them were individually picked for small-scale plasmid preparation. A total of 84 clones were found to contain cDNA inserts. Approximately $4 \mu \mathrm{g}$ of each recombinant plasmid was digested with Eco RI, ethanol-precipitated, resuspended, and denatured in $0.1 \mathrm{~N} \mathrm{NaOH}$ for $20 \mathrm{~min}$ at $70^{\circ} \mathrm{C}$. These were applied to Zetabind nylon membranes (AMF-CUNO) as 4 sets of dot blots and neutralized as described for colony screening (Hanahan and Meselson, 1983). Labeled cDNA probes were prepared as above with $1 \mu \mathrm{g}$ total cellular poly(A)+ RNA from normal and $p c d$ cerebellum and used to hybridize 2 dot blots each. Hybridization signals were compared visually.

Northern blot hybridization. Northern blots of RNA were prepared as previously described (Anderson and Axel, 1985) using Zetabind nylon membranes. Blots were prehybridized $6 \mathrm{hr}$ at $55^{\circ} \mathrm{C}$ in $10 \times$ Denhardt's solution, $0.75 \mathrm{M} \mathrm{NaCl}, 75 \mathrm{~mm}$ sodium citrate $(\mathrm{pH} 7.0), 0.5 \mathrm{mg} / \mathrm{ml}$ denatured salmon DNA, and $1 \%$ SDS. Blots were then hybridized 12 $18 \mathrm{hr}$ at $42^{\circ} \mathrm{C}$ in $1 \times$ Denhardt's solution, $0.75 \mathrm{M} \mathrm{NaCl}, 75 \mathrm{~mm}$ sodium citrate $(\mathrm{pH} 7.0), 0.1 \mathrm{mg} / \mathrm{ml}$ denatured salmon DNA, $1 \%$ SDS, $10 \%$ dextran sulfate, and $50 \%$ formamide. Probes were prepared by nick translation of the entire cDNA insert. After hybridization, blots were washed $1 \mathrm{hr}$ at $20^{\circ} \mathrm{C}$ in $0.15 \mathrm{M} \mathrm{NaCl}, 15 \mathrm{~mm}$ sodium citrate, $0.1 \% \mathrm{SDS}$, and for $1 \mathrm{hr}$ at $42^{\circ} \mathrm{C}$ in $15 \mathrm{~mm} \mathrm{NaCl}, 1.5 \mathrm{~mm}$ sodium citrate, $0.1 \%$ SDS. High-stringency washes were at $70^{\circ} \mathrm{C}$ instead of $42^{\circ} \mathrm{C}$. Blots were stripped between hybridizations by two or three $15 \mathrm{~min}$ washes in boiling 10 $\mathrm{mm}$ Tris- $\mathrm{HCl}$ (pH 7.5), 0.1\% SDS.

In situ hybridization. The procedure of Shivers et al. (1986) was followed. Eight-week-old DBA/2 mice were anesthetized with ether and perfused transcardially with $25 \mathrm{ml}$ calcium-free Tyrode's saline, $50 \mathrm{ml}$ $3 \%$ paraformaldehyde, and $30 \mathrm{ml} \mathrm{30 \%} \mathrm{sucrose.} \mathrm{Brains} \mathrm{were} \mathrm{stored} \mathrm{in}$ $30 \%$ sucrose for $1 \mathrm{hr}$ on ice before freezing on dry ice. Cryostat sections $(10 \mu \mathrm{m})$ were thaw-mounted onto subbed slides, dehydrated, and stored dessicated at $-75^{\circ} \mathrm{C}$. Sections were prehybridized $6 \mathrm{hr}$ at $22^{\circ} \mathrm{C}$ and hybridized $2 \mathrm{~d}$ at $37^{\circ} \mathrm{C}$ as described, using $10^{6} \mathrm{cpm}$ probe $/ \mathrm{ml}$ and no dextran sulfate. Probes were labeled by random oligonucleotide priming (Feinberg and Vogelstein, 1983) using $\left[\alpha^{35} \mathrm{~S}\right]-\mathrm{dCTP}(1300 \mathrm{Ci} / \mathrm{mmol})$. Restriction fragments of the cDNA clones used as probes are indicated in Figure 5. Hae III fragments of pUC119 were used as a control probe. 
A.
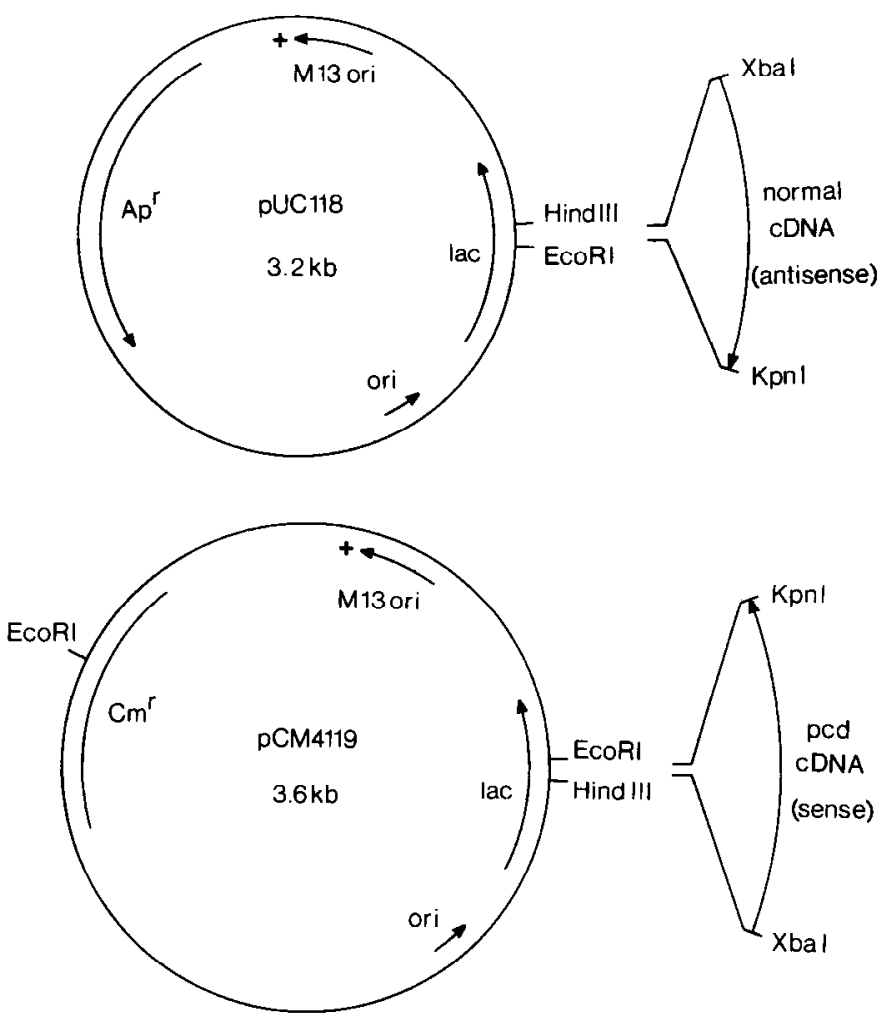

B.
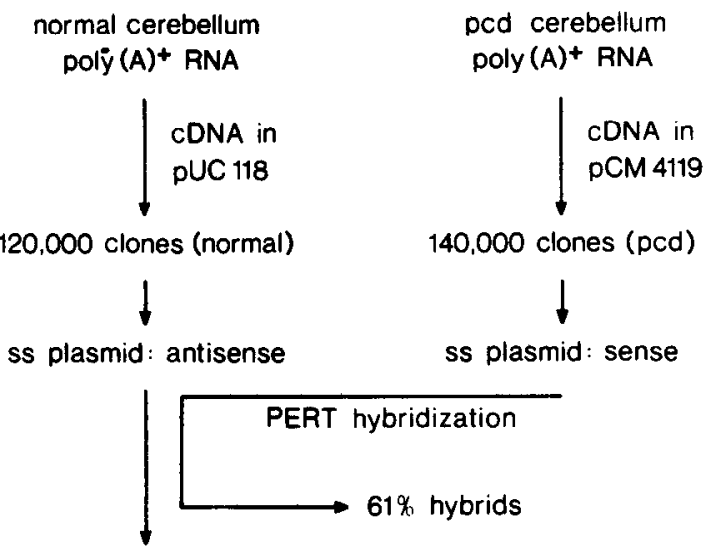

8000 clones (normal - pcd)

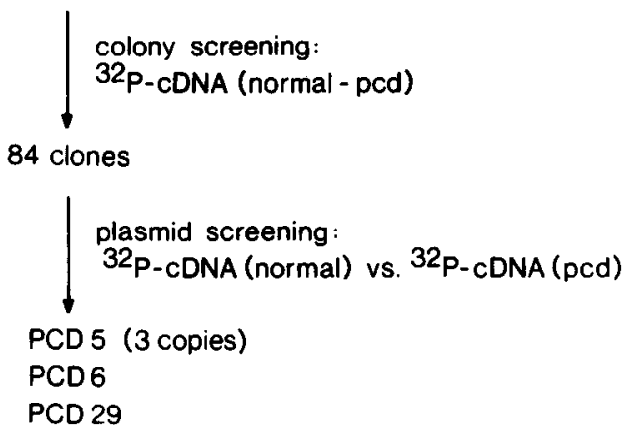

Figure 1. A, Orientation of normal and pcd cDNA in the vectors pUC118 and pCM4119, producing antisense and sense single-strand cDNA, respectively. $B$, Schematic description of the isolation of $5 \mathrm{cDNA}$ clones (detailed description in Materials and Methods).

Posthybridization washes were as described by Shivers et al. for ${ }^{35} \mathrm{~S}$ cDNA probes but substituted a $24 \mathrm{hr}$ wash in $7.5 \mathrm{~mm} \mathrm{NaCl}, 0.75 \mathrm{~mm}$ sodium citrate (pH 7.0), $0.05 \%$ sodium pyrophosphate, and $14 \mathrm{~mm}$ $\beta$-mercaptoethanol. Slides were coated with Kodak NTB-2 emulsion, developed after $5 \mathrm{~d}$ exposure, and stained with cresyl violet.

Sequencing. The dideoxy method was used (Sanger et al., 1977), with radiolabeling by $\left[\alpha^{35} \mathrm{~S}\right]$ dATP $(600 \mathrm{Ci} / \mathrm{mmol})$. Clones PCD2915 and PCD5029 were subcloned in pUC118 and pUC119 for sequencing. Clones PCD6035 and PCD6037 were subcloned in the Sma I site of M13 mp19 in both orientations and used for the production of overlapping templates as previously described (Dale et al., 1985). Sequences were determined from both strands except in some parts of the 3'untranslated regions. Data were stored and analyzed using IntelliGenetics software on the SUN 3/160 computer of the University of Minnesota, College of Biological Sciences, Molecular Biology Computer Facility.

Chromosome assignment. The mouse-hamster somatic cell hybrids used for the chromosome assignment of clones PCD5, PCD6, and PCD29 were derived from the fusion of BALB/c peritoneal cells with the Chinese hamster cell line E36, as previously described (Kozak and Rowe, 1979, 1980 ). Fourteen of the hybrids were karyotyped; the remainder were typed for markers on specific chromosomes. Genomic DNA (5-10 $\mu \mathrm{g})$ was digested with Eco RI and used for the preparation of Southern blots as described (Koller et al., 1985). Blots were prehybridized, hybridized, and washed as described above for Northern blots. Probes were labeled with ${ }^{32} \mathrm{P}$ by random oligonucleotide priming (Feinberg and Vogelstein, 1983) of the cDNA restriction fragments indicated in Figure 5.

\section{Results}

\section{Cloning of Purkinje cell $c D N A$}

As a means of finding cDNA clones representative of mRNA found in Purkinje cells but not in other cells of the cerebellum, we selected for sequences differentially expressed in normal adult mice and mice homozygous for the $p c d$ mutation. These mutant mice undergo specific Purkinje cell degeneration late in postnatal cerebellar development; by 6 weeks, there are virtually no Purkinje cells remaining, while secondary degenerations in the cerebellum are not yet observed (Mullen et al., 1976). Cerebella from 6 week $p c d$ mice should therefore lack only mRNA species unique to mature Purkinje cells, although loss of some mRNA species in other cell types cannot be excluded. To isolate corresponding Purkinje cell cDNA clones, we prepared an enriched population of normal cDNA by subtraction with $p c d$ cerebellar cDNA and screened with polyclonal cDNA probes made from normal and $p c d$ cerebellar mRNA.

Two cDNA libraries of over 100,000 clones each were constructed from 6 week normal C57BL/6J and C57BL/6J-pcd/pcd total poly(A) + cerebellar RNA. From these libraries, 2 types of single-strand plasmid DNA were produced: ampicillin-resistant, normal antisense-strand cDNA, and chloramphenicol-resistant, $p c d$ sense-strand cDNA (Fig. $1 A$ ). With this arrangement normal cDNA could be hybridized to an excess of $p c d$ cDNA and then selectively introduced into $E$. coli following removal of normal:pcd duplexes (Fig. $1 B$ ). PERT-hybridization conditions (Kohne et al., 1977) were found to be required to maintain the integrity of single-strand plasmid. The intent of the hybridization was to remove most of the sequences from high and medium abundance classes, or about $70 \%$ of the normal cDNA clones (Croizat et al., 1979). Lower abundance sequences should 


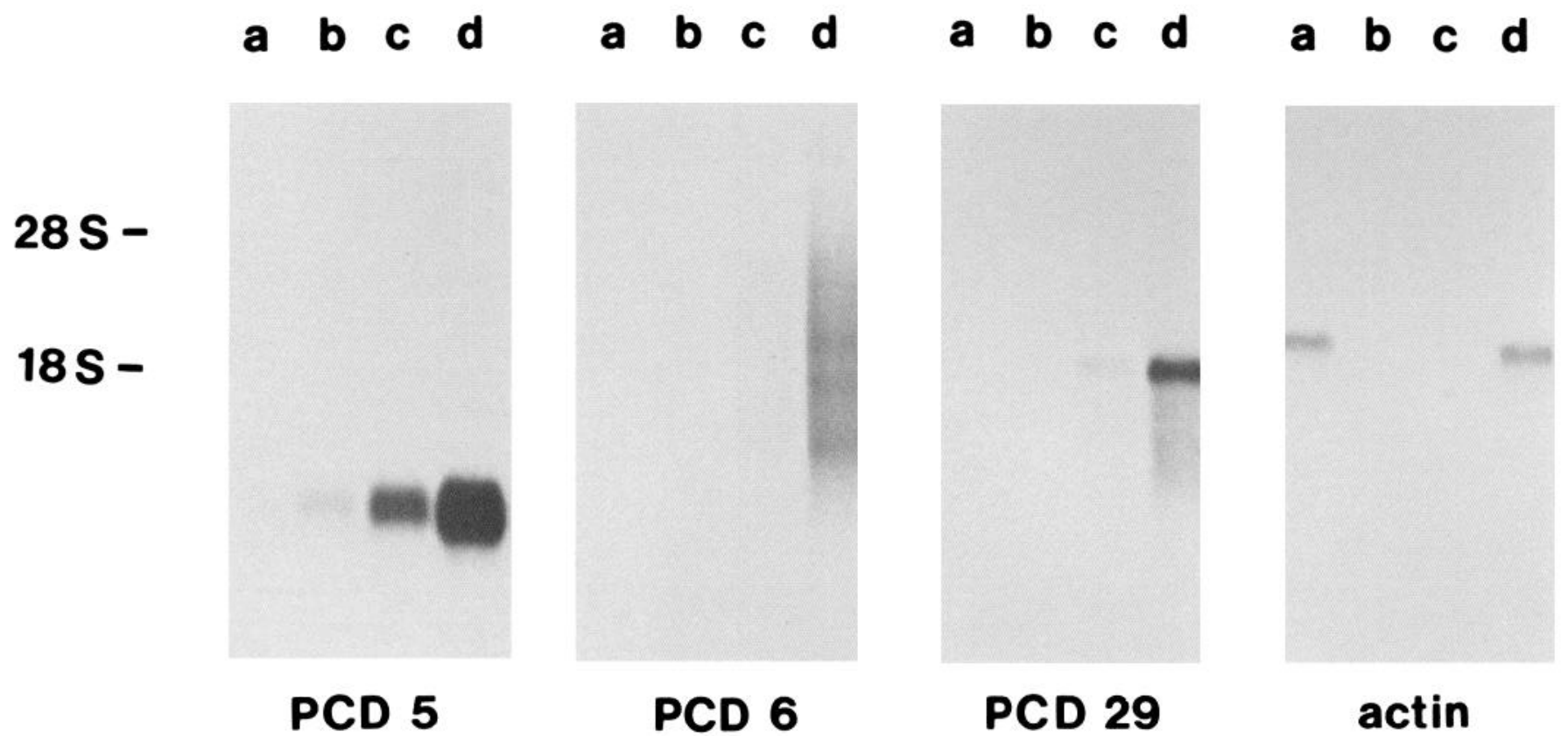

Figure 2. Northern blot hybridization of total cellular poly(A)+ RNA from the cerebella of 6 week normal C57BL/6J and C57BL/6J-pcd/pcd mice. Lane $a, 300 \mathrm{ng} p c d / p c d$ poly(A)+ RNA; lane $b, 3 \mathrm{ng}$ normal poly(A)+ RNA; lane c, 30 ng normal poly(A)+ RNA; lane d, $300 \mathrm{ng}$ normal poly(A)+ RNA. Hybridization to a mouse $\beta$-actin cDNA was used as a control. Autoradiograms are approximately equal exposures.

be undetectable during screening. The result of the subtraction was a $61 \%$ reduction of normal cDNA. This is less than a 3 -fold enrichment overall but should be a 10 - to 100 -fold enrichment of medium and high abundance sequences. A total of 8000 recombinant clones were obtained and screened with a normal cerebellar ${ }^{32} \mathrm{P}$-cDNA probe, from which approximately $50 \%$ of the activity had been removed by subtractive hybridization with $p c d$ sense-strand cDNA plasmid. After the primary screen, 84 clones were rescreened in duplicate as plasmid dot blots, using normal and $p c d$ cerebellum ${ }^{32} \mathrm{P}-\mathrm{cDNA}$ probes. Five of the plasmids gave strong signals with the normal probe but no signal with the $p c d$ probe. These represent 3 unique cDNAs, PCD5, PCD6, and PCD29, with PCD5 represented in 3 independent clones. To confirm the absence of mRNA expression in pcd cerebellum, cDNA inserts from each clone were used to probe Northern blots of total poly(A)+ cerebellar RNA (Fig. 2). No hybridization to pcd cerebellar mRNA could be detected with any of the PCD cDNAs. However, pcd cerebellar mRNA corresponding to clone PCD5 was clearly less than $1 \%$ of the amount present in normal cerebellum, in agreement with the remaining number of Purkinje cells observed in $p c d$ cerebellum (Mullen et al., 1976). Clones PCD5 and PCD29 detected mRNA molecules with an estimated size of 550-600 and $1800 \mathrm{nt}$, respectively. Clone PCD6 detected several mRNA bands, the smallest of which were approximately 1300,1700 , and $2200 \mathrm{nt}$ in length. The PCD6 hybridization pattern remained after rewashing the blot under high-stringency conditions (not shown).

\section{In situ and Northern hybridization}

The means by which the PCD clones were selected makes it likely that the corresponding mRNAs are unique to the Purkinje cells within cerebellum. We used in situ hybridization to examine the cellular distribution of mRNA in adult mouse cerebellum and Northern blot hybridization to examine the onset of mRNA expression in immature cerebellum. Hybridization of perfusion-fixed 8 week DBA/2 cerebellum with ${ }^{35} \mathrm{~S}$-cDNA probes showed specific labeling of Purkinje cells by each of the PCD clones (Fig. 3). This result does not exclude the possibility of low-level mRNA expression in other cells; however, comparison with the hybridization to pcd cerebellar mRNA in Northern blots (Fig. 2) suggests that little if any expression of these mRNAs occurs in other cerebellar cell types. To characterize the onset of mRNA expression in developing cerebellum, cDNA probes were hybridized to Northern blots of total cellular cerebellar RNA from postnatal day 1 through 20 (Fig. 4). Very low levels of mRNA were detected on postnatal day 1 with the PCD5 and PCD29 probes, while none was seen with PCD6. With each of the probes, mRNA was observed to increase steadily until reaching a maximum level by day 15 . This increase in mRNA parallels the development of the Purkinje cell dendritic arbor and axon collaterals from postnatal day 10 through 20 (Landis, 1973).

RNA expression outside of the cerebellum was examined by Northern blot hybridization of mRNA from cerebrum, olfactory lobe, and various other mouse tissues. This study revealed that the expression of mRNA corresponding to the PCD clones is not limited to cerebellum (Fig. 4). Clone PCD29 hybridized to mRNA from olfactory lobe, cerebrum, kidney, and eye. Clone PCD6 also hybridized strongly to mRNA from throughout the brain and gave weak signals to mRNA from testis and kidney (distinct mRNA bands could not be seen in total cellular RNA due to the presence of rRNA). Clone PCD5 gave the most restricted hybridization pattern of the 3 clones, as mRNA was detected only in cerebellum and eye (presumably retina).

\section{DNA sequence analysis}

To determine if any of the PCD clones had been previously described and to allow generation of antibodies to synthetic peptides, we determined their DNA sequences. For this purpose longer clones were obtained from a cDNA library made from 
A.

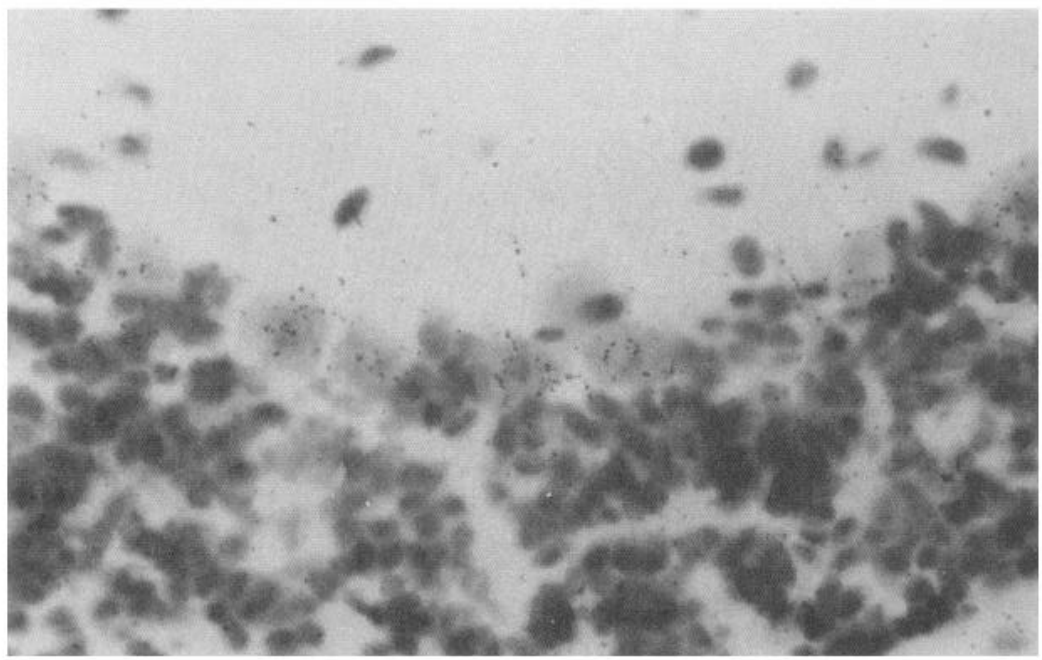

B.

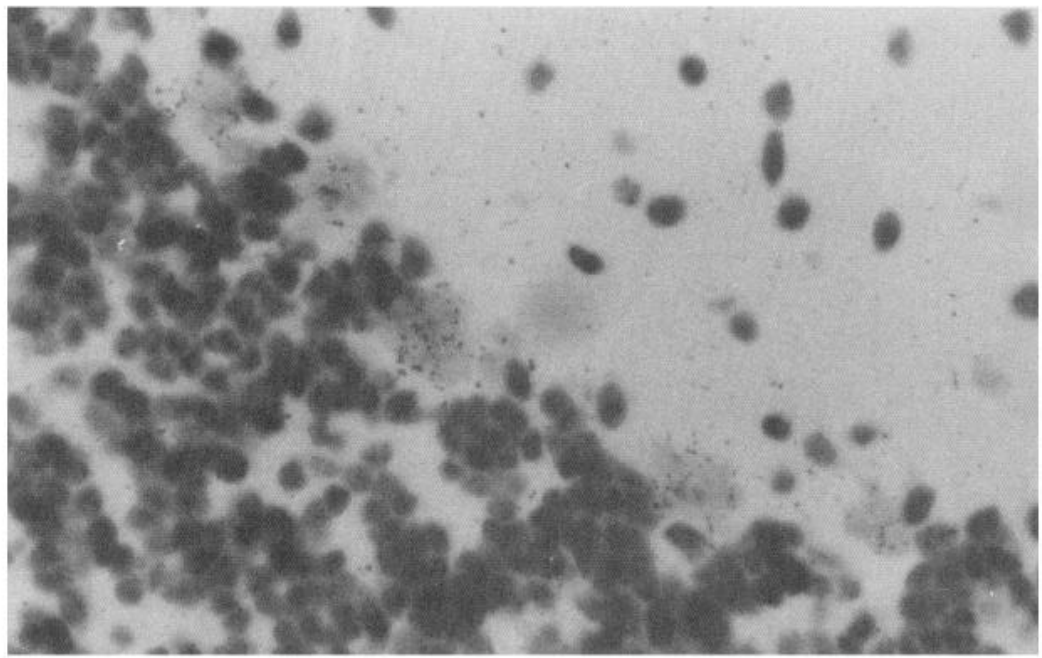

Figure 3. In situ hybridization of mRNA in 8 week DBA/2 mouse cerebellum. Cresyl violet-stained parasagittal sections were photographed in bright field at $400 \times$ magnification. $A$, Probed with PCD5029a (PCD5). $B$ Probed with PCD6035a (PCD6). $C$, Probed with PCD2915.1 (PCD29, calbindin- $\left.\mathrm{D}_{28 \mathrm{~K}}\right)$. Probes are described in Figure 5.

C.

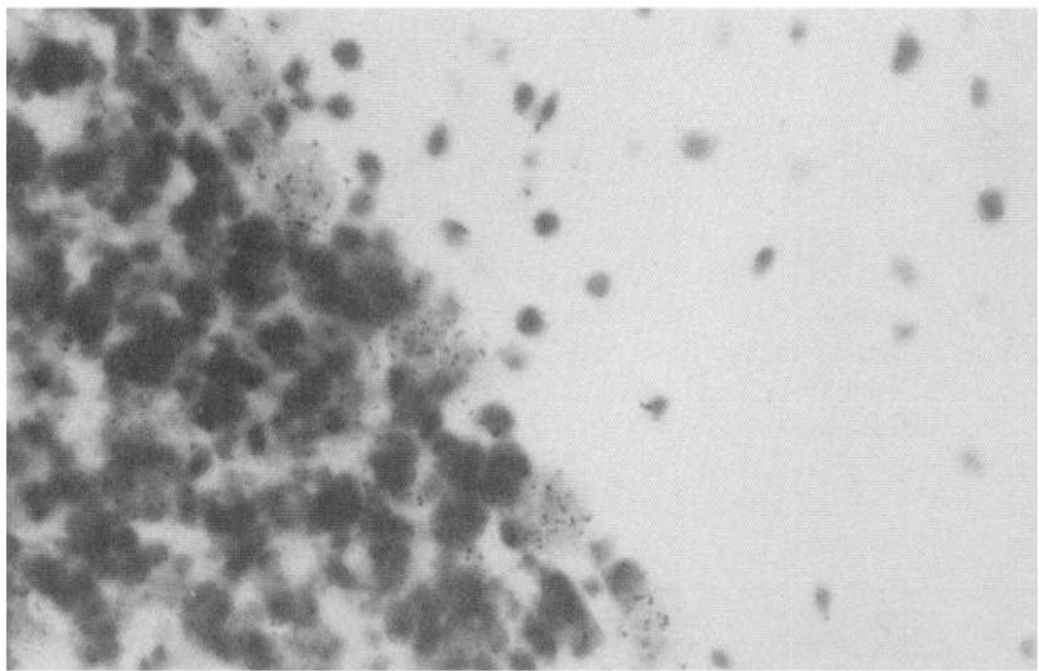

cytoplasmic poly(A)+ cerebellar mRNA. Nearly full-length clones were isolated for PCD29 (PCD2915) and PCD5 (PCD5029), based on their comparison with the mRNA size determined by Northern hybridization. Clone PCD2915 has a
1781 base pair (bp) cDNA insert, including an $80 \mathrm{nt}$ poly(A) region; the corresponding mRNA in cerebellum is approximately 1.8 kilobase $(\mathrm{kb})$ in length. The sequence of this clone encodes a $30 \mathrm{~K}$ protein (Fig. 5) that has a 6 domain structure 


\section{$\begin{array}{lllllllllllllll}1 & 5 & 10 & 15 & 20 & \text { CB } & C & O & E & T & K & \text { I } & \text { L } & \text { H } & \text { M }\end{array}$}

\section{PCD 5}
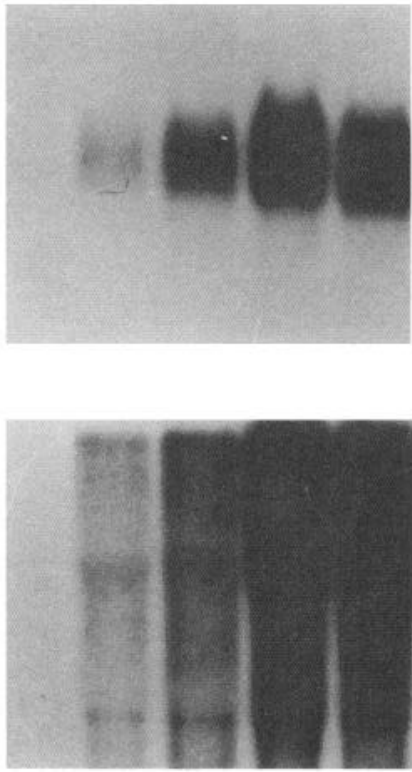

PCD 6

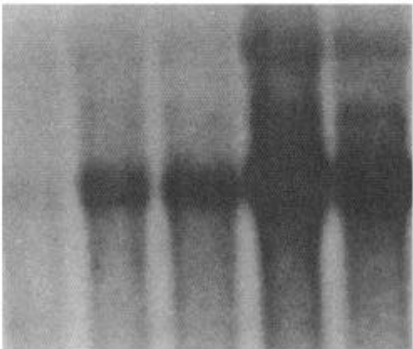

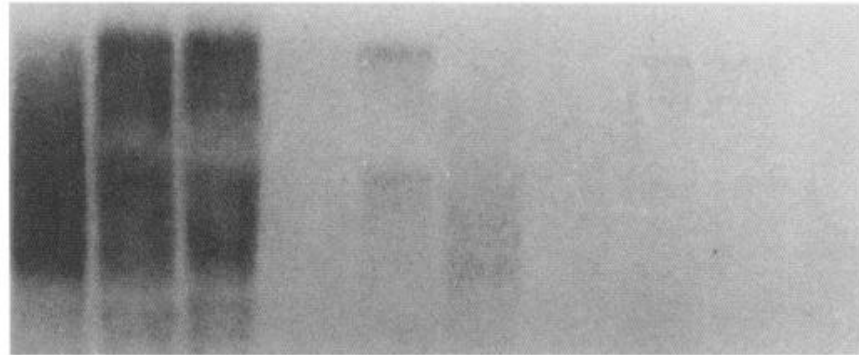

$-9.5 \mathrm{~kb}$

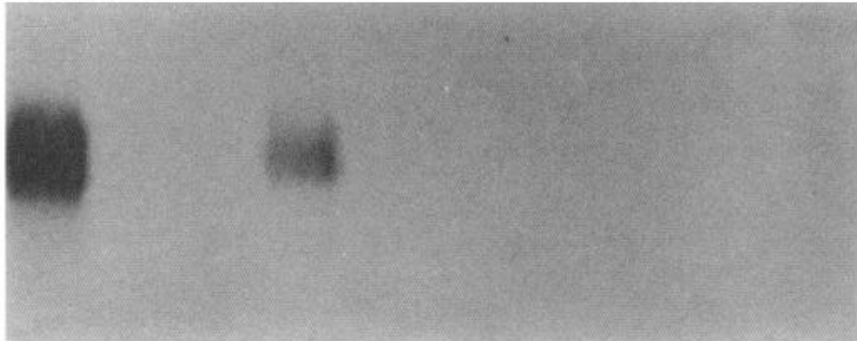

$-0.6 \mathrm{~kb}$

$-1.6 \mathrm{~kb}$

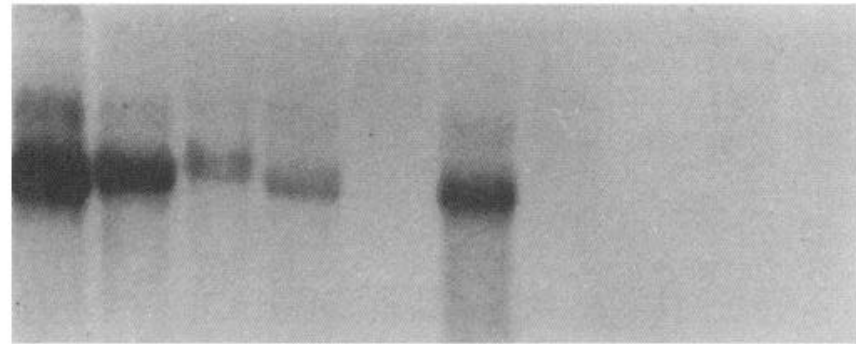

$-1.8 \mathrm{~kb}$

Figure 4. Postnatal expression of mRNA corresponding to the PCD clones. Lanes 1, 5, 10, 15, and 20 contain $10 \mu \mathrm{g}$ total cellular RNA from C57BL/6J mouse cerebellum isolated at postnatal day $1,5,10,15$, and 20 . Lane $C B$ contains $300 \mathrm{ng}$ total cellular poly(A)+ RNA from 6 week $\mathrm{C} 57 \mathrm{BL} / 6 \mathrm{~J}$ cerebellum. The remaining lanes each contain $10 \mu \mathrm{g}$ total cellular RNA isolated from adult DBA/2 or B10.S mice: $C$, cerebrum; $O$, olfactory lobe; $E$, eye; $T$, testis; $K$, kidney; $I$, intestine; $L$, liver; $H$, heart; $M$, skeletal muscle.

with 4 apparently functional calcium-binding sites (Kretsinger and Nockolds, 1973). PCD29 was concluded to encode the cytoplasmic calcium-binding protein calbindin- $\mathrm{D}_{28 \mathrm{~K}}$ (Wasserman, 1985 ) based on size, calcium-binding potential (Bredderman and Wasserman, 1974), and tissue distribution (Wasserman and Feher, 1977; Jande et al., 1981). Comparison of this mouse sequence with other published sequences found a $78 \%$ amino acid identity with chick calbindin- $\mathrm{D}_{28 \mathrm{~K}}$ (Wilson et al., 1985; Hunziker, 1986; Fullmer and Wasserman, 1987) and a $99 \%$ amino acid identity with the predicted rat protein (Yamakuni et al., 1987).

Clone PCD5029 has a 530 bp cDNA insert that includes a $65 \mathrm{nt}$ poly(A) region; the corresponding mRNA in cerebellum was estimated to be 550-600 $\mathrm{nt}$ in length. The sequence of this clone has an opening reading frame of 99 amino acids (Fig. 5) and encodes a $10.7 \mathrm{~K}$ protein. The predicted protein does not contain a leader peptide typical of secreted products. Sequence data banks contained no DNA or protein sequences similar to PCD5029.

Several mRNA bands corresponding to PCD6 are observed in total cellular poly(A) + RNA from cerebellum (Fig. 2), ranging in size from approximately 1.3 to $9.5 \mathrm{~kb}$. This same pattern was seen in cytoplasmic poly(A) + RNA, indicating that the bands represent fully processed RNA transcripts (data not shown). To determine if differential RNA processing might occur, 2 cDNA clones having different restriction maps, PCD6035 and PCD6037, were analyzed. These were found to have identical overlapping sequences but to differ in that PCD6037 has an extended 3'-untranslated region (not shown). This difference can be attributed to the use of a second poly $(\mathrm{A})$-addition signal (AATAAA) $798 \mathrm{nt}$ downstream from the signal used in PCD6035. Differential use of polyadenylation signals, however, cannot explain the $1.3 \mathrm{~kb}$ mRNA band, which may be the result of differential mRNA splicing. Clone PCD6035 extends further than PCD6037 in the 5'-direction and has an open reading frame of 500 amino acids (Fig. 5); there is no evidence that the clone is full-length. The predicted protein sequence has no obvious transmembrane region or leader peptide. No protein or DNA sequence similarity was found to PCD6035 in data bank searches.

\section{Chromosomal localization of the PCD genes}

Several mutations in the mouse that affect cerebellum are believed to act intrinsically in the Purkinje cell ( $p c d$, lurcher, beige, 
PCD 2915

CCGAACGGAGCAGCACCGCGGACACGCRCCGCCGCGCCGCGCCCAGCTCAGCCTGCGCAGCCC TCT CGCCCGAGGTTCGCGCTCCGCGCACTCTCAAACTAGCCGCTGCACCACGATGGCAGAAT Metalagluser

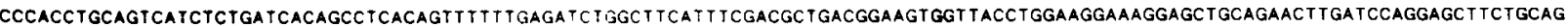

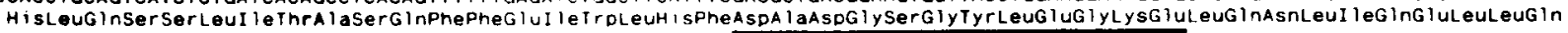

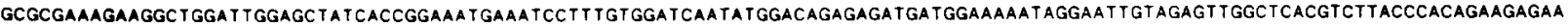

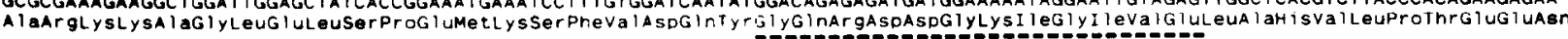

TITTIGCTGCICTITCGATGCCAGCAACTGAAGTCCTGCGAGGAATTCATGAAGACT TGgAGAAAGTATGATACTGACCACAGCGGC TICATCGAAACCGAGGAACTTAAGAACTTTCTAAAGG

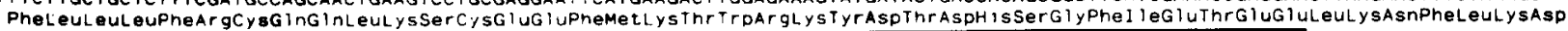

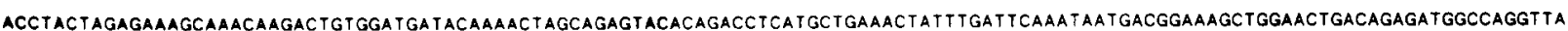

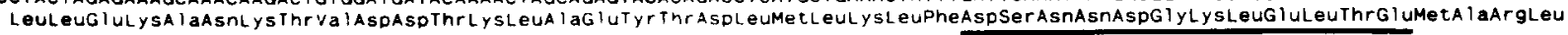

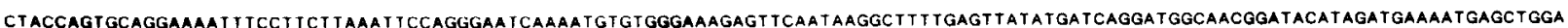

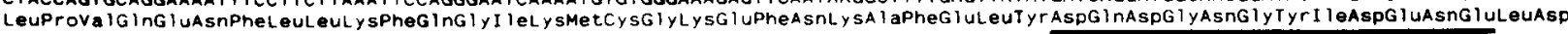

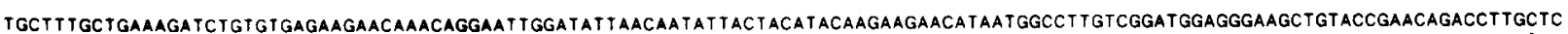

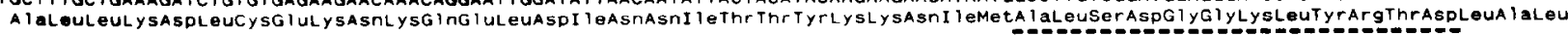
TTATTCTITCTGCTGGAGACAACTAGAGTTGGTGACCACAACCACTTGCTAGTGATACATIGTATCTAAAACCATAACTGTGCGCTATAAAGAAGTAGGC TGTATTITCTTTTATATCTGTAAAT

I lel euseral aGlyaspasn

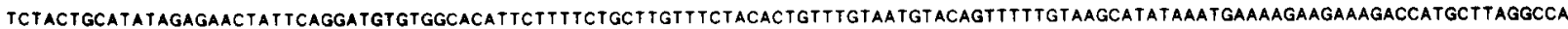

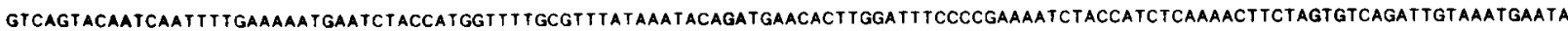
TCTGTCAT TGAGT AAAAGAATAACTCATGGCAAGCCAACTGTTTTTATTTTAGGCAACCATAGGACTGTCACCCAAAGCACCTCTGTGCTGCTTCTATCTGGCGGAaGgGaTGGGCTTCTGCCTC

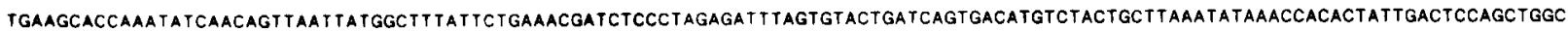
TTGGTAAGgGaAgTAGCCAGATGACACATAACTATGTCTGATTCTATGCCTATATTTCCAAGAAGTCTACTGCCAGAGAGTATGACCATAGCCCATTTTCTAAATTATTTTCATGTGTTCCAGA

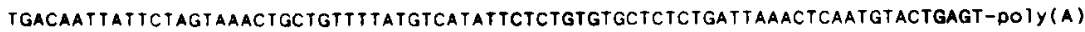

PCO 5029

TAGGTACTAGGATTTAGGGGCACTTCTGAGCCCCATTTCCCTGGCAGgTTCACCGGACCAGgAagCTTCTTCAACCTGCTGACCCACGTGCAGgGCGATCGgATGgAGgaGCAGCGCTGT TCCT MetglugluginargcysserLeu

TGCAGGCTGGGCCAGGCCAGAACCCAGAAAGCCAGGgTGGCCCTGCTCCAGAGATGgACAATCTCATGGATATGCTGGTCAACACCCAGGGCCGCCGCATGGACGACCAGCGTGTAACAGTTAAT

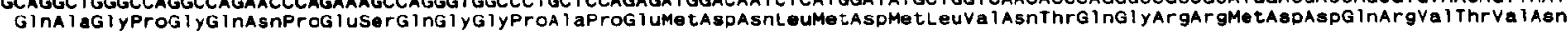
TCCCTOCCTGGCTICCAACCTATCGGCCCCAAGGAIGGAAT GCAGAAACGACCTGGGACCCTCAGCCCTCAACCCCTGCTCACCCCTCAGGATCCTGCTGCACTCAGCTTCCGCAGGAACAGCAG

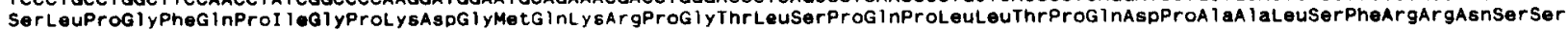
CCCCCAOCCCCAGACACAAGCTCCTTGAGAGTTCTAGCCATCCTGGGCCTCCCACTGGCCCCTGAAAACAATAAAACACTTGGCACTAGC-DOIY(A) ProginProglnthrglnalapro

PCD 6035

TITAACGAGATGAACTGGCAGAAGAAACTTCGAGCCCAGCCTGTCTTGIACIGGIGTGCCCGAAACA IGICII ICI GGAGCAGCATCTCCT TCAACCTGGCCGTCCTGATGAACCTGCTGGTGGC

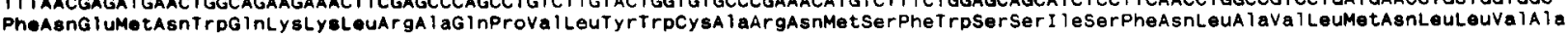
GTTTTICTATCCATITAAAGGAGTAAGgGGagGaACACTAGAGCCACACTGGTCAGGCCTTCTGTGGACAGCCATGCTCATCTCTCTGGCCATTGTCATTGCTCTGCCCAAGCCCCACGGCATCC

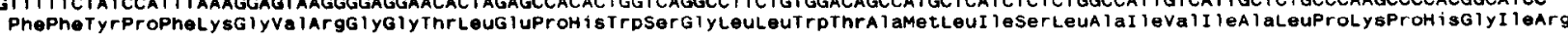
GGGCCITAATTGCTTCTACAATCCTACGACTGATATTTTCAGTTGGGT TGCAGCCCACACTGTTTCTGCTGGGAGCTTICAATGTCTGCAATAAAATCATCTTCCTGATGAGCTTTGTGGGCAAC

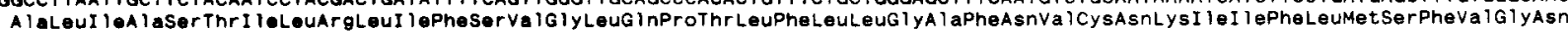
TGTGGGACCTTCACCAGAGGCTACCGGGCCATGGTTCTGGATGTGGAGTTCCTCTATCATTTGCTGTATCTACTCATCTGTGCCATGGGCCTCTTCGTACATGAGT TCT TCTATAGCTTGCTGCT CYBGIyThrPheThrargGIYTy TTT TGATTTAGTGTACAGAGAGgAGACTT TGCTTAATGTCATTAAAAGTOTCACCCGCAATGGACGGTCCATCATCTTGACAGCGGTCCTGGCTCTGATCCTGGTTTACCTGTTCTCAAT TGTGG PheagpleuvalTy

GCTATCTGTTCTTCAAGGATGACTTTATCTTGGAAGTAGATAGGTTGCCCAATGAACAGCTGTTCCAGAAACTGGCGAGAGTTTGGCCAACGATTTCCTGTACTCTGATGTGTGCAGGGTAGAG

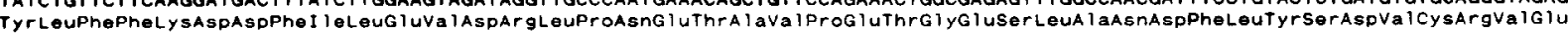

ACGGGGGAGAACTGCACCTCTCCTGCACCCAAAGAAGAGCTGCTCCCTGCCGAAGAAACGGAACAGGATAAGGAACACACGTGTGAGACCCTGCTCATGTGCATCGTCACTGT ICTGAGTCACGG

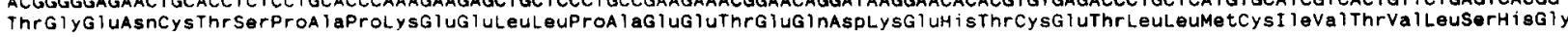
GCTGCGGAGTGGGGGAGGGTAGGAGACGTGCTCAGGAAGCCATCCAAAGAGGAGCCTCTGTTTGCTGCAAGGGTGATCTACGACCTCCTCTTCTTCTTCATGGTCATCATCATCGTCCTGAACC

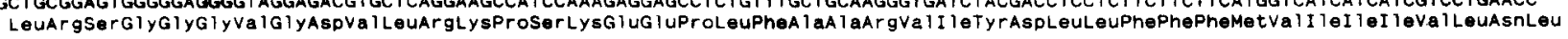
TGATTTTCGGGGTCATCATTGACACCTT TGCTGACCTGAGGAGTGAGAAGCAAAAGAAGGAGGAGATCT TAAAAACCACGTGCTMCATCTGCGGCTTGGAAAGGGACAAGTTTGACAATAAGACT

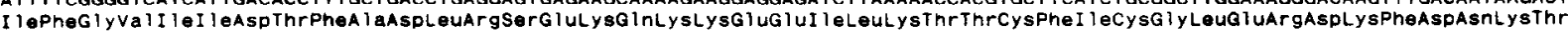
GTCACCTTIGAAGAGCACATCAAGGAAGAGCACAACATGTGGCACTATCTGTGCTTCATCGTGCTGGTGAAAGTGAAGGACTCCACAGAGTACACCGGGCCTGAGAGTTACGTGGCAGAGATGAT

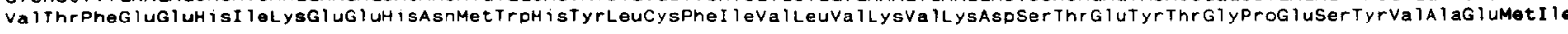
CAGGGAAGAAACCTIGATTGGT TCCCCAGAATGAGAGCCATGTCCCTGGTCAGCAGCGATTCTGAAGgGGAACAGAACGAGCTGAGGAACCTGCAGGAGAaGCTGGAGICTACCATGAAGCTGG

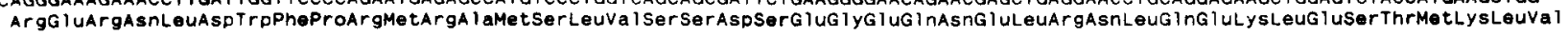

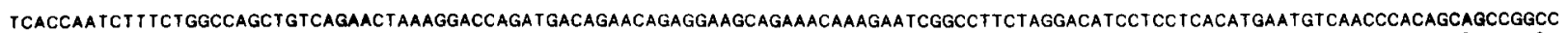

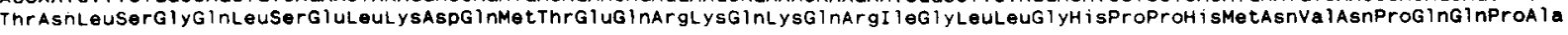
IAGGCAAATGAGgCAGAGgGaCTCTGCTCAGCCCTCTGTATATCACTGTCAGGGTGGGTACGGCICATIGGITCIGATT TGCCCACTAAGGGTACATGTGCGCTTAGTACATTTGTAAATACTCA GTTITGTATIGTATGTATATGATIGCTATTCTCAGAGGTTTGGACTTTCGTATTGTAATTAGCTCTGT TGGCATGGTGACTTGTCACTCCTGCCAAAAATATTAAAAATGCCTTTTTTGGAAGGA CIACAGAAAGTACCTGATT TGCACT TGAACCAGATTATAGATITAAAAGTATATGACATGTATTTTGIATTTAAAACTAGAATAGCCAGTATTTATGTTTITTATAAAACTGTGCAATACAAATT ATGCAATCACCATAACTTTGTAACTCCTGAGTGTCCTAAGgGagTACACATCTTTGAAGCTGATTTGT TGATACTCGTGTAATAAATGGTTAAATATC-DO IY(A)

Figure 5. DNA sequences and open rcading frames of 3 PCD cDNA clones. Solid lines in the sequence of PCD2915 (mouse calbindin- $\mathrm{D}_{28 \mathrm{~K}}$ ) indicate 4 putative calcium-binding regions; dashed lines indicate 2 regions with sequence similarity but not expected to bind calcium. Probes used for in situ hybridization and chromosomal mapping were derived from these clones: PCD2915.1 (positions 1-425), PCD5029a (positions 1-345), and PCD6035a (positions 596-954). 
staggerer), and a number of others may be suspected of being primary Purkinje cell defects (Sidman, 1983). Since the PCD clones represent mRNA species expressed in Purkinje cells but absent or at low levels in other cerebellar cell types, it is reasonable to ask whether any of the clones may correspond to one of these mutant genes. This question was approached initially by comparing the genomic locations of PCD sequences and mutant genes. To localize the PCD sequences to specific mouse chromosomes, cDNA inserts from the PCD clones were hybridized to Southern blots of Eco RI-digested DNA from mousehamster somatic cell hybrids (Kozak and Rowe, 1979, 1980).

Probe PCD2915.1 (Fig. 5) hybridized to Eco RI fragments of 3.8 and $5.6 \mathrm{~kb}$ in the parent mouse and Chinese hamster DNA, respectively. Three mouse-hamster hybrids out of 12 tested were positive for the mouse $3.8 \mathrm{~kb}$ band. None of the hybrids tested was discordant for the cosegregation of the PCD29 gene and mouse chromosome 4 , while greater than $17 \%$ discordancy was noted with all other chromosomes (Table 1). The gene for PCD 29 (calbindin- $\mathrm{D}_{28 \mathrm{~K}}$ ) was therefore assigned to mouse chromosome 4. The mutation meander tail (mea), which causes the reduction of Purkinje and granule cell populations in mouse cerebellum, also maps to this chromosome (Hollander and Waggie, 1977).

Probe PCD5029a (Fig. 5) was found to hybridize with an Eco $\mathrm{RI}$ fragment of $5.0 \mathrm{~kb}$ in the mouse, and with fragments of 3.2 and $0.9 \mathrm{~kb}$ in Chinese hamster. Of the 19 mouse-hamster hybrids tested, 5 were positive for the mouse $5.0 \mathrm{~kb}$ fragment. None of the hybrids tested was discordant for the cosegregation of the PCD5 gene and mouse chromosome 8 , while at least $21 \%$ discordancy was noted with other mouse chromosomes (Table 1). Two mutations affecting Purkinje cell viability also map to mouse chromosome 8: leaner $\left(t^{1 \mathrm{a}}\right)$ and nervous $(n r)$ (Sidman, 1983).

Probe PCD6035a (Fig. 5) detected an Eco RI band of $5.0 \mathrm{~kb}$ and a less intense band of $4.3 \mathrm{~kb}$ in the mouse, and a $5.6 \mathrm{~kb}$ band in Chinese hamster. Ten out of 19 mouse-hamster hybrids were positive for both mouse bands; one additional hybrid, HM4, showed only a weak $5.0 \mathrm{~kb}$ band. Only one discordancy (5\%) was noted for the cosegregation of the PCD6 gene with mouse chromosome 6 and was due to the weak hybridization observed in hybrid HM4. At least $26 \%$ discordancy was noted for all other chromosomes (Table 1), indicating that the gene for PCD6 does map to mouse chromosome 6 . The mutation lurcher $(L r)$, which causes Purkinje and granule cell degeneration, is also located on this chromosome (Sidman, 1983).

\section{Discussion}

We have described the use of the mouse mutant Purkinje cell degeneration ( $p c d$; Mullen et al., 1976) for the identification of cDNA clones corresponding to mRNA expressed in mature Purkinje cells but absent or at very low levels in other cerebellar cell types. Since the screening procedure relies on the use of polyclonal cDNA probes synthesized from poly $(\mathrm{A})+$ cerebellar RNA, there are inherent limitations in clone detection. In our experiment it was estimated that the cDNA probe must constitute at least $0.01 \%$ of the total probe mass to produce a colony hybridization signal above background. RNA species of lower abundance, which constitute the majority of expressed genes in the cerebellum (Croizat et al., 1979), may be expected to be undetectable as cDNA clones. A second limitation derives from the required use of tissue mRNA, in which cell-type-specific mRNA species become diluted. Thus, if Purkinje cells contrib- ute less than $10 \%$ of poly(A) + cerebellar RNA, cell-specific clone detection would be limited to species constituting greater than $0.1 \%$ of poly(A) + Purkinje cell RNA. Although few in comparison with the total number of expressed genes, these relatively high abundance mRNA species are likely to encode proteins that are of fundamental importance to the unique structures or activities of Purkinje cells.

In our experiment, 3 cDNA clones that represent mRNA unique to the Purkinje cells were isolated from an enriched population of normal cerebellar cDNA clones. Although the enrichment procedure should have removed most high and medium abundance clones common to the normal and pcd libraries, in numerical terms the enrichment was less than 3-fold. Taking into account the randomization of clones during library amplification and single-strand production, a 99\% complete screening for clones of $>0.01 \%$ abundance would require probably 50,000 clones; only 8000 clones were screened in this experiment. The recently reported use of lurcher cerebellar cDNA probes to identify Purkinje cell cDNA (Oberdick et al., 1987) also resulted in 3 identified cDNA clones, none of which corresponds in description with the PCD clones.

Clone PCD29 was shown to encode the cytoplasmic calcium binding protein calbindin- $\mathrm{D}_{28 \mathrm{~K}}$ (Wasserman, 1985). This protein has been found throughout the CNS with a high concentration in cerebellum, where it is restricted to Purkinje cells (Jande et al., 1981). The mouse calbindin sequence from PCD2915 was found to have a 6 domain structure with 4 intact calcium binding regions, as previously noted for calbindin in chicken (Hunziker, 1986) and rat (Yamakuni et al., 1987). We observed that the 6 domains of calbindin have a particularly strong sequence similarity with the 2 calcium-binding domains of parvalbumin (Kretsinger and Nockolds, 1973). Domains 1, 3, and 5 of calbindin are similar to parvalbumin domain 1 and have a characteristic central Gly-Phe/Tyr dipeptide that is highly conserved in parvalbumin across many vertebrate species (Maeda et al., 1984). Domains 2, 4, and 6 are similar to parvalbumin domain 2 and are highly conserved at the central Gly-Lys dipeptide. Although calbindin domains 2 and 6 are lacking key residues required to form a calcium-coordination complex, they have been predicted to retain the E-F hand structure of the calciumbinding domains (Fullmer and Wasserman, 1987).

It has been suggested that calbindin- $\mathrm{D}_{28 \mathrm{~K}}$ contributes greatly to the calcium-buffering potential of Purkinje cells (Baimbridge et al., 1982). Genetic mutations affecting this protein should therefore be detrimental to these neurons, perhaps causing cell death. By Southern analysis of mouse-hamster somatic cell hybrids, we have mapped the gene for calbindin- $\mathrm{D}_{28 \mathrm{~K}}$ to mouse chromosome 4 . This chromosome is also the site of the mutation meander tail (mea), which causes abnormalities of the caudal vertebrae and a reduction of Purkinje and granule cell populations in cerebellum (Hollander and Waggie, 1977; Sidman, 1983). If calbindin in kidney is involved in calcium resorption, it is conceivable that calbindin dysfunction could lead to hypocalcemia and osteodysplasia similar to that observed in mea mice. It is not known if the mea defect in cerebellum is intrinsic to Purkinje cells, but the concomitant reduction of both Purkinje and granule cell populations has been noted in 2 other mutants believed to be primary Purkinje cell defects: lurcher $(L r)$ and staggerer ( $\mathrm{sg}$ ) (Sidman, 1983).

Unlike PCD29, clones PCD5 and PCD6 did not show any structural similarity with any sequences in DNA or protein data banks. We found that the gene for PCD5 mapped to mouse 
Table 1. Correlation between specific mouse chromosomes and PCD DNA markers in mouse-hamster somatic cell hybrids

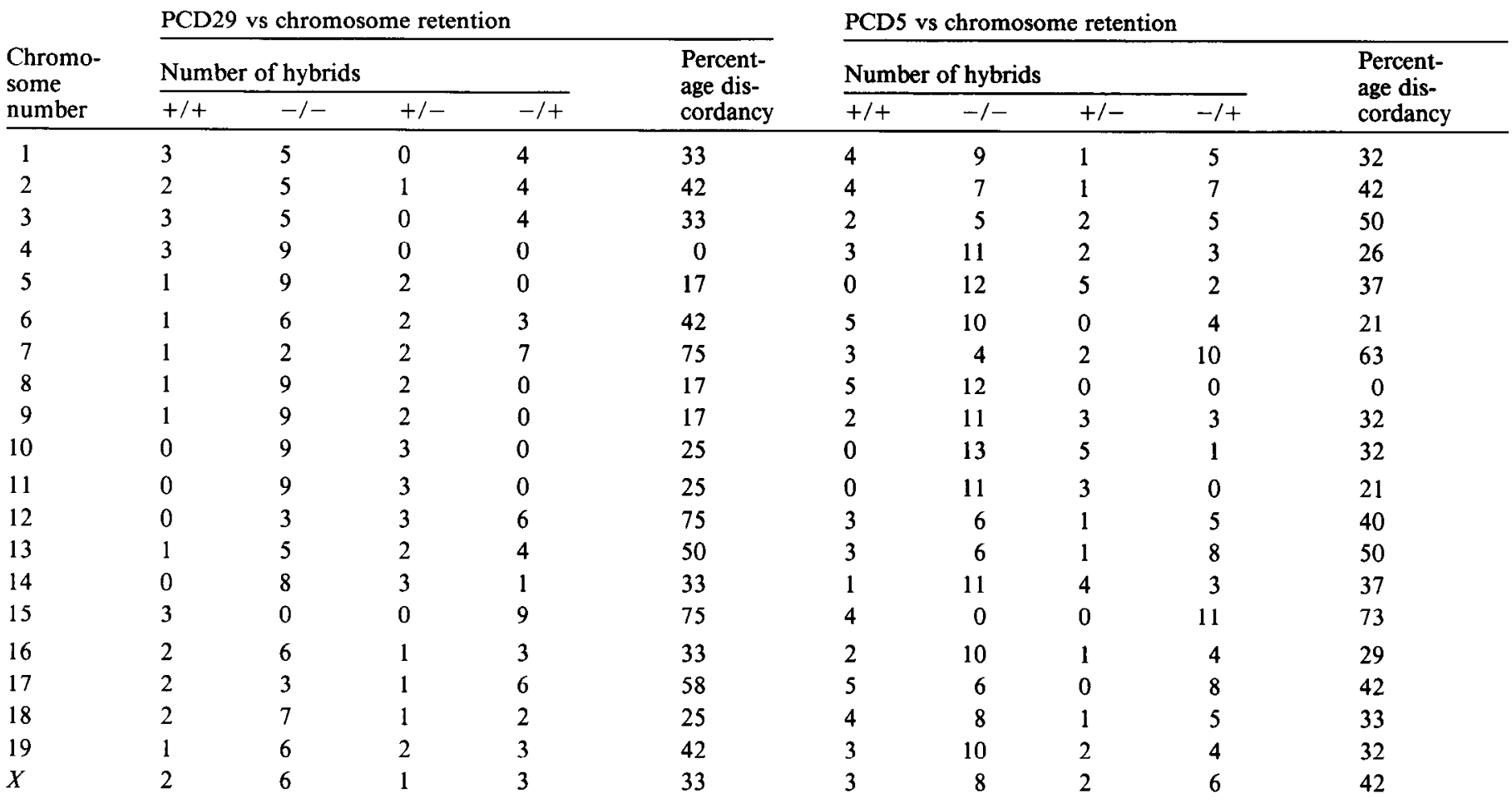

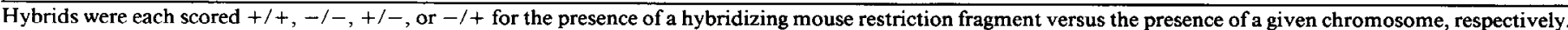

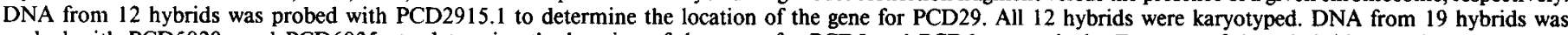

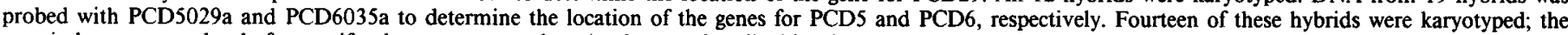
remainder were typed only for specific chromosome markers (probes are described in Fig. 5).

chromosome 8 . It is possible that PCD5 may correspond to the genes nervous $(n r)$ or leaner $\left(\operatorname{tg}^{1 \mathrm{a}}\right)$, based on the chromosomal assignment of these mutants and their effect on the viability of Purkinje cells (Sidman, 1983). The association of PCD5 and $n r$ is particularly interesting: PCD5 hybridized to mRNA only in the cerebellum and eye, while $n r$ causes the specific degeneration of Purkinje cells in cerebellum and of photoreceptor cells in the retina (Landis, 1973; Mullen and LaVail, 1975). The gene for PCD6 mapped to mouse chromosome 6 and may be considered a candidate for the mutant gene lurcher $(L r)$, which is believed to be an intrinsic Purkinje cell defect (Sidman, 1983).

During the postnatal development of cerebellum, mRNA corresponding to the PCD clones showed a similar rate of increase and reached a maximum level by day 15 , when the Purkinje cells have attained a mature phenotype. The gradual increase in this mRNA cxpression may be duc in part to variance in the stage of neuronal maturation throughout the cerebellum (Altman, 1969), but it may also be taken to imply that transition to the mature Purkinje cell phenotype is a gradual process involving different levels of gene activity. Although common to the Purkinje cells in cerebellum, these genes will not necessarily be similar in their pattern of mRNA expression outside of cerebellum. This was seen with the clones PCD5, PCD6, and PCD29, each of which showed different patterns of hybridization to RNA from different brain regions and from several nonneural tissues.

Note added in proof: Using recombinant inbred mouse strains to map gene positions on mouse chromosome 4, clone PCD29 (calbindin- $\mathrm{D}_{28 \mathrm{~K}}$ ) was found to be distinct from mea (B. Mock, personal communication).

\section{References}

Altman, J. (1969) Autoradiographic and histological studies of postnatal neurogenesis. III. Dating the time of production and onset of differentiation of cerebellar microneurons in rats. J. Comp. Neurol. 136: 269-294.

Anderson, D. J., and R. Axel (1985) Molecular probes for the development and plasticity of neural crest derivatives. Cell 42: 649-662.

Baimbridge, K. G., J. J. Miller, and C. O. Parkes (1982) Calciumbinding protein distribution in the rat brain. Brain Res. 239: 519-525.

Bredderman, P. J., and R. H. Wasserman (1974) Chemical composition, affinity for calcium, and some related properties of the vitamin $D$ dependent calcium-binding protein. Biochemistry 13: 1687-1694. Chirgwin, J. M., A. E. Przybyla, R. J. MacDonald, and W. J. Rutler (1979) Isolation of biologically active ribonucleic acid from sources enriched in ribonuclease. Biochemistry 18: 5294-5299.

Croizat, B., F. Berthclot, A. Felsani, and F. Gros (1979) Complexity of polysomal polyadenylated RNA in mouse whole brain and cortex. FEBS Lett. 103: 138-143.

Dale, R. M. K., B. A. McClure, and J. P. Houchins (1985) A rapid single-stranded cloning strategy for producing a sequential series of overlapping clones for use in DNA sequencing: Application to sequencing the corn mitochondrial $18 \mathrm{~S}$ rDNA. Plasmid 13: 31-40.

Davis, M. M., D. I. Cohen, E. A. Nielson, M. Steinmetz, W. E. Paul, and L. Hood (1984) Cell-type-specific cDNA probes and the murine I region: The localization and orientation of $A^{d}$. Proc. Natl. Acad. Sci. USA 81: 2194-2198.

Feinberg, A. P., and B. Vogelstein (1983) A technique for radiolabeling DNA restriction endonuclease fragments to high specific activity. Anal. Biochem. 132: 6-13.

Fullmer, C. S., and R. H. Wasscrman (1987) Chicken intestinal 28kilodalton calbindin-D: Complete amino acid sequence and structural considerations. Proc. Natl. Acad. Sci. USA 84: 4772-4776. 


\begin{tabular}{|c|c|c|c|c|}
\hline \multicolumn{5}{|c|}{$\begin{array}{l}\text { Table 1. Continued } \\
\text { PCD6 vs chromosome retention }\end{array}$} \\
\hline \multicolumn{4}{|c|}{ Number of hybrids } & \multirow{2}{*}{$\begin{array}{l}\text { Percent- } \\
\text { age dis- } \\
\text { cordancy }\end{array}$} \\
\hline$+/+$ & $-1-$ & $+1-$ & $-1+$ & \\
\hline 7 & 7 & 4 & 1 & 26 \\
\hline 7 & 4 & 4 & 4 & 42 \\
\hline 5 & 5 & 4 & 0 & 29 \\
\hline 3 & 7 & 8 & 1 & 47 \\
\hline 0 & 7 & 11 & 1 & 63 \\
\hline 10 & 8 & 1 & 0 & 5 \\
\hline 9 & 2 & 2 & 6 & 42 \\
\hline 5 & 7 & 5 & 0 & 29 \\
\hline 3 & 7 & 8 & 1 & 47 \\
\hline 0 & 7 & 11 & 1 & 63 \\
\hline 0 & 6 & 8 & 0 & 57 \\
\hline 6 & 2 & 3 & 4 & 47 \\
\hline 8 & 5 & 2 & 3 & 28 \\
\hline 3 & 7 & 8 & 1 & 47 \\
\hline 9 & 0 & 0 & 6 & 40 \\
\hline 4 & 6 & 5 & 2 & 41 \\
\hline 9 & 4 & 2 & 4 & 32 \\
\hline 6 & 4 & 5 & 3 & 44 \\
\hline 5 & 5 & 6 & 3 & 47 \\
\hline 6 & 6 & 5 & 2 & 37 \\
\hline
\end{tabular}

Gruol, D. L., and C. L. Franklin (1987) Morphological and physiological differentiation of Purkinje neurons in cultures of rat cerebellum. J. Neurosci. 7: 1271-1293.

Gubler, U., and B. J. Hoffman (1983) A simple and very efficient method for generating cDNA libraries. Gene 25: 263-269.

Hall, C., and L. Lim (1984) Preparation of frec and mcmbranc-bound polyribosomes from rat forebrain. In Molecular Biology Approach to the Neurosciences, H. Soreq, ed., pp. 151-153, Wiley, New York.

Hanahan, D. (1984) Techniques for transformation of E. coli. In Gene Cloning, D. M. Glover, ed., pp. 109-135, Chapman and Hall, New York.

Hanahan, D., and M. Meselson (1983) Plasmid screening at high colony density. Methods Enzymol. 100: 333-342.

Hollander, W. F., and K. S. Waggie (1977) Meander tail: A recessive mutant located on chromosome 4 of the mouse. J. Hered. 68: 403406.

Hunziker, W. (1986) The 28-kDa vitamin D-dependent calcium-binding protein has a six-domain structure. Proc. Natl. Acad. Sci. USA 83: 7578-7582.

Ito, M. (1984) The Cerebellum and Neural Control, Raven, New York.

Jande, S. S., L. Maler, and D. E. M. Lawson (1981) Immunohistochemical mapping of vitamin D-dependent calcium-binding protein in brain. Nature 294: 765-767.

Kohne, D. E., S. A. Levison, and M. J. Byers (1977) Room temperature method for increasing the rate of DNA reassociation by many thousandfold: The phenol emulsion reassociation technique. Biochemistry 16: 5329-5341.

Koller, B. H., F. E. Ward, R. DeMars, and H. T. Orr (1985) Comparison of multiple HLA-A alleles at the DNA level by using Southern blotting and HLA-A-specific probes. J. Immunol. 135: 4229-4234.

Kozak, C. A., and W.P. Rowe (1979) Genetic mapping of the ecotropic murine leukemia virus-inducing locus of $\mathrm{BALB} / \mathrm{c}$ mouse to chromosome 5. Science 204: 69-71.
Kozak, C. A., and W. P. Rowe (1980) Genetic mapping of the ecotropic virus-inducing locus $A k v-2$ of the AKR mouse. J. Exp. Med. 152: 1419-1423.

Kretsinger, R. H., and C. E. Nockolds (1973) Carp muscle calciumbinding protein: Structure determination and general description. J. Biol. Chem. 248: 3313-3326.

Landis, S. C. (1973) Ultrastructural changes in the mitochondria of cerebellar Purkinje cells of nervous mutant mice. J. Cell. Biol. 57: 782-797.

Lohmann, S. M., U. Walter, P. E. Miller, P. Greengard, and P. De Camilli (1981) Immunohistochemical localization of cyclic GMP-dependent protein kinase in mammalian brain. Proc. Natl. Acad. Sci. USA 78: 653-657.

Maeda, N., D. Zhu, and W. M. Fitch (1984) Amino acid sequences of lower vertebrate parvalbumins and their evolution: Parvalbumins of boa, turtle, and salamander. Mol. Biol. Evol. 1: 473-488.

Marusyk, R., and A. Sergeant (1980) A simple method for dialysis of small-volume samples. Anal. Biochem. 105: 403-404.

Mullen, R. J., and M. M. LaVail (1975) Two new types of retinal degeneration in cerebellar mutant mice. Nature 258: 528-530.

Mullen, R. J., E. M. Eicher, and R. L. Sidman (1976) Purkinje cell degeneration, a new neurological mutation in the mouse. Proc. Natl. Acad. Sci. USA 73: 208-212.

Nilaver, G., R. Defendini, E. A. Zimmerman, M. C. Beinfeld, and $T$. L. O'Donohue (1982) Motilin in the Purkinje cell of the cerebellum. Nature 295: 597-598.

Oberdick, J., F. Levinthal, and C. Levinthal (1987) L7 is a marker for the terminal differentiation of Purkinje cells in mouse cerebellum. Soc. Neurosci. Abstr. 13: 377

Okayama, H., and P. Berg (1982) High-efficiency cloning of full-length cDNA. Mol. Cell. Biol. 2: 161-170.

Padgett, R. A., G. M. Wahl, P. F. Coleman, and G. R. Stark (1979) $\mathrm{N}$-(Phosphonacetyl)-L-aspartate-resistant hamster cells overaccumulate a single mRNA coding for the multifunctional protein that catalyzes the first steps of UMP synthesis. J. Biol. Chem. 254: 974 980.

Roderick, T.H., and M. T. Davisson (1984) Linkage map of the mouse (Mus musculus). In Genetic Maps, Vol. 3, S. J. O'Brien, ed. Cold Spring Harbor Laboratory, Cold Spring Harbor, New York.

Sanger, F., S. Nicklen, and A. R. Coulson (1977) DNA sequencing with chain-terminating inhibitors. Proc. Natl. Acad. Sci. USA 74: 5463-5467.

Shivers, B. D., B. S. Schachter, and D. W. Pfaff (1986) In situ hybridization for the study of gene expression in the brain. Methods Enzymol. 124: 497-510.

Sidman, R. L. (1983) Experimental neurogenetics. In Genetics of Neurological and Psychiatric Disorders, S. S. Kety, L. P. Rowland, R. L. Sidman, and S. W. Matthysse, eds., pp. 19-46, Raven, New York.

Slemmon, J. R., W. Danho, J. L. Hempstead, and J. I. Morgan (1985) Cerebellin: A quantifiable marker for Purkinje cell maturation. Proc. Natl. Acad. Sci. USA 82: 7145-7148.

Vieira, J., and J. Messing (1987) Production of single-stranded plasmid DNA. Methods Enzymol. 153: 3-11.

Wasserman, R. H. (1985) Nomenclature of the vitamin D-induced calcium-binding proteins. In Vitamin D: Chemical, Biological, and Clinical Update, A. W. Norman, K. Schaefer, H.-G. Grigoleit, and D. von Herrath, eds., pp. 321-322, deGruyter, Berlin.

Wasserman, R. H., and J. J. Feher (1977) Vitamin D-dependent calcium-binding proteins. In Calcium-Binding Proteins, R. H. Wasserman, R. A. Corradino, E. Carafoli, R. H. Kretsinger, D. H. MacLennan, and F. L. Seigel, eds., pp. 293-302, Elsevier, Amsterdam.

Weber, A., and M. Schachner (1984) Maintenance of immunocytologically identified Purkinje cells from mouse cerebellum in monolayer culture. Brain Res. 311: 119-130.

Wilson, P. W., M. Harding, and D. E. M. Lawson (1985) Putative amino acid sequence of chick calcium-binding protein deduced from a complementary DNA sequence. Nucleic Acids Res. 13: 8867-8881.

Yamakuni, T., R. Kuwano, S. Odani, N. Miki, K. Yamaguchi, and Y. Takahashi (1987) Molecular cloning of cDNA to mRNA for a cerebellar spot 35 protein. J. Neurochem. 48: 1590-1596. 